\title{
Alternate Bearing in Fruits Trees: A Review
}

\author{
Ashok Kumar ${ }^{1 *}$, B. D. Bhuj ${ }^{2}$ and C. P. Singh ${ }^{2}$ \\ ${ }^{1}$ Department of Horticulture, SGT University, Gurgram, Haryana, [NCR Delhi], India \\ ${ }^{2}$ College of Agriculture, G.B.P.U.A \&T-Pant Nagar, U.P., India \\ *Corresponding author
}

\section{Keywords}

Mango (Mangifera indica L., Fruit production, Cultivar evaluation, Breeding, Irrigation

Article Info

\section{Accepted:}

12 December 2020

Available Online:

10 January 2021

\section{A B S T R A C T}

Alternate Bearing is an alternating pattern of large and small crops occurring in many fruit species that is internally regulated by the plant. Alternate bearing in mango appeared to be related to complex relationships between vegetative and reproductive growths and it is varied according to the cultivar. Flowering is the main event that set the stage for mango production each year. For the attaining the fruit flower initiation is very important and it is very complex phenomena in mango. Flowering is the main event that set the stage for mango production each year. For the attaining the fruit flower initiation is very important and it is very complex phenomena in mango. In mango trees flowering is make them especially challenging for physiologists, breeders, and growers. North, east and central Indian commercial cultivars showed the biennial bearing is very serious problem, while most of the south Indian varieties bear regularly. Therefore, different control measures for the biennial bearing are application of different chemicals, smudging, pruning etc. most widely used in view of its high potential mango production. This review classifies the multiple hypotheses as internal, genetic, carbohydrate resources and hormones or environmental, abiotic and biotic stresses. The biennial bearing or alternate bearing habit of mango (Mangifera indica L.) is a major problem for its commercial cultivation for getting expected productivity, alternate bearing, alternate year cropping, irregular bearing or cropping, periodicity in mango cropping, biennial bearing, are all synonymous terms which are different from the unfruitfulness and shy cropping.

\section{Introduction}

Mango (Mangifera indica L.) is an evergreen tree in the family Anacardiaceae grown for its edible fruit. The mango tree is erect and branching with a thick trunk and broad, rounded canopy. The tree produces dense clusters of flowers with cream-pink petals on branched panicles. Alternate Bearing means an alternating cropping pattern of the tree that is internally. Regulated by the plant. This alternate bearing pattern is common in many of the perennial trees and shrubs but is not universal. Apple is one of the heavily-studied fruit crops with regard to alternate bearing because of its high economic importance. Alternate bearing is an important economic problem for a number of fruit and nut growers worldwide. Under normal conditions, olive trees produce heavy crops one year (the "on" 
year) and light ones the next (the "off" year). Experience has shown that large olive yields tend to lead to smaller crops the following year. The potential light crop is predictable from the limited amount of new growth present in the trees. The previous heavy crop limits shoot growth and, because flowers are produced only on the new shoots of the previous season, the tree's potential for olive production is reduced. This alternate bearing is one of the most important limitations of natural extensive olive cultivation.

The mechanism(s) by which the developing crop influences return bloom and yield the following year is not fully understood. Two hypotheses have been suggested. The "nutritional" hypothesis holds that return bloom and yield are proportional to tree carbohydrate status. Lack of carbohydrate in the ON year directly or indirectly reduces flowering the following year. Support for this hypothesis has been provided by showing positive correlations between carbohydrate levels and $\mathrm{AB}$ status, whereas others have shown no consistent relationship between tree carbohydrate status and floral intensity at return bloom. The "hormonal" hypothesis proposes that developing fruit produce an inhibitor that directly or indirectly reduces flowering in the spring following the $\mathrm{ON}$ crop.

Although a number of studies have shown correlations between abscisic acid or indole3-acetic acid and $\mathrm{AB}$ status, no direct evidence has been provided for their involvement in the return bloom. Gibberellins (GA) is well-known inhibitor of flowering in citrus; thus, fruit-produced GA has been presumed to be involved in AB. Despite these findings, the roles of carbohydrates and hormones in $\mathrm{AB}$ remain unclear and more research is needed to identify factors affecting floral intensity following $\mathrm{ON}$ and OFF years. Genetic analysis of $\mathrm{AB}$ in apple identified a few QTLs associated with AB, and suggested that hormone-related genes are likely to play a role in the phenomenon. Once a woody perennial plant has passed the juvenile period when it cannot be induced to flower and has reached its adult phase of reproductive competence, a proportion of its meristems will initiate floral organs annually.

Flowering in temperate tree species can be divided into several stages that include flower induction, flower initiation, flower differentiation, and blooming. Flower initiation is the key developmental stage for fruit trees, particularly for horticultural crops such as the apple (Malus $\times$ domestica Borkh.), because it determines the success of commercial orchards (Buban and Faust, 1982)(4) by its influence on fruit quantity and quality (Link, 2000)(21), as well as stability of production from year to year (Schmidt et al., 1989)(32). Flower initiation can be strongly limited by an excessive crop, leading to the phenomenon known as biennial bearing (Jonkers, 1979; Monselise and Goldschmidt, 1982) (20, 26, 14). Commonly used terms related to alternate bearing include biennial bearing and irregular bearing. Biennial bearing is characterized by large yields of small sized fruit in 'on' years, and low yields, sometimes even no fruit, in 'off' years. This alternation is a widely spread phenomenon, occurring in both deciduous and evergreen trees, and in different tree families and species such as nuts (hazelnuts, pecans, pistachios, and walnuts), temperate fruits (apple, apricot, pears, and prunes), subtropical fruits (avocados, citrus, and olives), tropical fruits (litchis and mangos), and forest trees (beeches, oaks, pines, and spruces) (Monselise and Goldschmidt, 1982)(14).

Although generations of scientists have tried to understand this phenomenon, the cause of alternate bearing is still largely unknown (Hoad, 1978; Jonkers, 1979; Monselise and 
Goldschmidt, 1982; Bangerth, 2006, 2009) $(19,20,26,14,3)$. External factors (photoperiod, temperature, and water stress), internal factors such as the carbon-to-nitrogen ratio and hormones (auxins, cytokinins (CKs), abscisic acid, ethylene, and gibberellins (GAs)), as well as interaction with other organs (leaves, terminal shoot growth, and fruit) affect flower formation in apple (for reviews, see Hanke et al., 2007; Bangerth, 2009) (17,2). The negative relationship between fruit development and flower bud differentiation is one of the most investigated causes of flower set variability in apple, as the differentiation of flower buds in apple overlaps with embryo development in the previous season's fruit (Harley, 1942; Foster et al., 2003)(18,13), leading to competition between flower initiation and fruit formation.

Experiments using 'Spencer Seedless', which can bear both parthenocarpic and seeded fruit, suggested that seed development rather than nutritional competition may be a factor in alternate bearing (Chan and Cain, 1967; Neilsen and Dennis, 2000)(7,27). The number of seed per fruit or per bourse (flowering growth unit) has an effect on biennial bearing, which can be overcome by a high vegetative growth rate of the bourse shoot itself (Chan and Cain, 1967; Grochowska and Karaszewska, 1976; Hoad, 1978; Neilsen and Dennis, 2000) $(7,15,19,27)$. Seed are known to contain relatively large amounts of hormones (Luckwill, 1974) (22), and auxin (indole acetic acid (IAA)), GA, and CK have been implicated separately, and in combination, as being responsible for hormonal control of floral induction (FI).

IAA and GA may act together or independently to inhibit FI in perennial fruit trees, whereas CK is likely to be the hormone enhancing FI (Bangerth, 2006)(3). Although the spur (short fruiting shoot) tissues of biennial bearing cultivars receive more GA through the pedicel than annual bearing cultivars do (Hoad, 1978)(19), and the peak activity of GA in apple seed coincides with FI (Luckwill, 1970)(23), it has been difficult to obtain convincing evidence for the transport of GA from seed in sufficient quantities to inhibit FI. Bangerth (2006)(3) proposed that auxin could be the mobile signal and might stimulate GA synthesis in the meristem. In this model, GA and auxin could potentially act as FI-inhibiting signals working in concert, GA as the primary messenger that stimulates the synthesis/transport of the second messenger auxin. However, characterization and quantification of both GA and auxin in the meristem still need to be performed and, moreover, an inhibitory effect of GA/auxin and stimulation by $\mathrm{CK}$ on the expression of genes related to FI remain to be demonstrated (Bangerth, 2006)(3).

\section{Technologies to induce regular bearing in mango}

The flowering phenomenon in mango is a complex one. Normally, it crops heavily in one year (on year) and bears less or no crop the following year (off year). Again, it yields heavily the next year. Thus the rhythm of bearing in mango is not strictly 'alternate' but 'irregular' or 'erratic'. Research findings have clearly indicated that this phenomenon is mostly due to varietal as well as environmental factors in addition to the orchard management practices including pruning, nutrition, irrigation and plant protection.

\section{Possible causes for irregular bearing}

\section{Varieties}

Among the most important commercial varieties of the North Dashehari, Langra, Chausa, Fazri and South, Neelum ( Kazaladdu), Banganapalli ( Sappatai) 
Bangalora (Kizhimooku, Totapuri) Kalepad and Senthura (Chinnaswarnarekha) are moderate to heavy bearers and are considered to be fairly regular. Choice varieties such as Alphonso (Gundu), Imam Pasand (Himayuddin), Mulgoa, Peter (Pairi, Nadusalai) etc., are mostly erratic in bearing.

\section{Weather conditions}

Though mango is a hardy tree an adverse weather condition can convert an 'on year' into an 'off-year'.

Bearing age: Fruit trees purchased from nurseries and garden centres are usually 1 - to 2-years-old when they are sold. The length of time from planting to fruit bearing varies with the species of fruit, the cultivar, and whether the tree is dwarf or standard size (see table). Differences in bearing age also exist among cultivars. This is particularly true for apples and pears. In general, those cultivars that have an upright growth habit, such as Red Delicious, tend to be tardy coming into bearing, while those with a spreading growth habit, such as Jonathan, tend to be early.

Deficit rainfall- It is quite evident during mango season of 2010 when almost all the varieties failed to flower in Tamil Nadu. It is mainly due to the deficit rainfall which was about $300 \mathrm{~mm}$ less than that of the previous year's average annual rainfall of Tamil Nadu.

If frequent showers occur during the period of fruit-bud differentiation (October November) and flowering (January) with cloudy weather and excessive dew, both flowering and fruit set would be adversely affected. Dry and cool weather with a day /night temperature around 200 / 150 C during winter season trigger flowering induction. Recommended management practices that help to induce regular bearing in mango

\section{Regular pruning is very essential}

Need based fertilizer application based on the soil test report have to be followed. Spraying of Potassium nitrate at 2 per cent + NAA 40 ppm (or) Potassium dihydrogen phosphate at 1 per cent + Potassium nitrate at 1 per cent during October. Spraying of 0.5 per cent urea, if the trees do not flower up to January. In the irrigated orchards, soil drenching of Paclobutrazol at $1 \mathrm{ml} / \mathrm{m}\{+2\}$ of canopy area.

Flower induction in mango during 'off'
year

Alternate bearing is a serious problem prevailing in many choice varieties; rhythm of 'On' (heavy crop) and 'Off' (lean or no crop) years occurs consecutively; profitability of mango orcharding is affected. Commercial varieties of Uttar Pradesh, Dashehari, Langra, Chausa, Bombay Green and Lucknow Safeda, are alternate bearers. Application of paclobutrazol @3.2 ml per meter canopy diameter through soil drenching during September is found to induce flowering even during 'Off' year. In case of Dashehari, full dose of paclobutrazol in the first year followed by half dose in the second year is required. In Chausa and Langra, regular applications are necessary. This technology was found to increase in Dashehari, 'On' year yields by about 25 per cent, while providing 60 per cent of the normal yield during 'Off' years. This approach since operates through checking of vegetative growth /vigour, it is important to adopt good cultural practices for sustaining tree health in the long run. It is widely adopted in Maharashtra state (Konkan region) in Alphonso production.

\section{Environmental factors}

Light: Good exposure to sunlight is one of the most important factors influencing the formation of flower buds on fruit trees. 
Through the process of photosynthesis, the leaves on the tree manufacture sugars used for vegetative growth, flower bud formation, and fruit development. If sunlight is limited, the tree will continue to grow, but there will not be sufficient sugars for the formation of flower buds. Under such conditions, young trees will be slow coming into bearing, the blossoms will be sparse, and the fruit that forms will be poorly colored. Dwarf trees also will grow larger than anticipated. For these reasons, fruit trees should be planted in locations where they will receive maximum sunlight. Avoid shaded sites near buildings or other trees.

Water: The lack of sufficient water, as experienced under drought conditions, can have both a positive and a negative influence on the formation of flower buds. If a temporary drought occurs early in the growing season, during the period of flower bud formation, it can be beneficial in promoting flower buds. However, if the same drought continued or a prolonged drought developed later in the season, it could result in the loss of flower buds. To prevent such a loss, fruit trees should be watered during periods of prolonged drought, particularly if they are planted near other trees. Flower bud formation occurs between mid-June and mid July. If conditions are favorable, the buds continue to develop until flowering the following spring.

Temperature: Low temperatures during winter and spring through bloom can result in the loss of flower buds. During the winter, temperatures below $-18^{\circ} \mathrm{F}$ to $-20^{\circ} \mathrm{F}$ will kill the flower buds of peaches and sweet cherries, while the flower buds of apples, pears, sour cherries, and plums are able to withstand colder temperatures. However, if the temperature drops severely following a January or February thaw, the killing temperature for flower buds of even the hardiest species is much higher. The greatest injury to the flower buds occurs when rather warm periods in the early spring are followed by unseasonably cold temperatures. With such warm periods, the buds begin to break dormancy and swell. As the buds become more active, they become increasingly sensitive to cold temperature and are most sensitive at bloom.

Cultural practices: Cultural practices that influence the vigor and vitality of the tree will affect its ability to bear fruit early and consistently produce crops. Poor cultural practices often result in a tree that lacks vigor and vitality. Such trees may start bearing, but fruit production is inconsistent from year to year. These trees are unable to produce enough food reserves to carry a crop, make new growth, and have something left over to form flower buds for the following year. This ultimately leads to biennial bearing. However, practices that promote excessive vigour will inhibit or delay fruiting. With excessive vigour the manufactured sugars are utilized for vegetative growth and little sugar remains to form flower buds. One of the easiest ways to judge tree vigour is to observe the amount of shoot growth the tree makes each year. Generally, a tree capable of carrying a crop is judged to have sufficient vigour if the average terminal shoot growthis in the range of 12 to 18 inches. More vigor is desired with young trees, but as the tree approaches bearing age, cultural practices should be geared toward discouraging excessive vigour.

Fertilization: For young fruit trees in the backyard, over fertilization with nitrogen is one of the major reasons for excessive tree vigour and the lack of fruit. Such trees can easily receive too much nitrogen when the lawn around the tree is fertilized. For this reason, it is recommended that fruit trees be fertilized well (about 1/4 lb. actual nitrogen) just after planting to encourage good growth. 
Then, depending on the tree vigor, either withhold or cut back on the nitrogen until the tree begins to bear. This means reducing the rate of nitrogen applied to the lawn around the tree. Once the tree is bearing, normal lawn fertilizer rates should be adequate for most trees. To fertilize bearing fruit trees independently of the lawn, use a rate of $0.1 \mathrm{lb}$. of actual nitrogen per inch of the tree trunk diameter at its narrowest point. The fertilizer should be broadcast under the tree. Observe the amount of terminal shoot the tree makes each year to make adjustments to this recommended rate.

Pruning and training: Proper training and pruning dictate the potential production of a fruit tree. Fruit trees should be pruned to develop a strong framework and improve light penetration through the tree. Low light intensity is the primary reason for few flowers and poorly colored fruit toward the centre of a tree. As with excessive fertilizer applications, excessive pruning encourages vigorous shoot growth at the expense of flower bud formation. This is particularly true for young non-bearing trees. In order to encourage early fruiting on young trees, pruning should be kept to a minimum and be confined to developing a good framework. For trees that have begun to fruit, the amount of pruning required each year can be judged by observing the amount of terminal shoot growth. If the average terminal shoot growth is excessive, then less wood should be removed than was taken the previous year. If terminal shoot growth is less than normal and the previous crop was not great, then more wood removal compared to the previous season is warranted. For more information on pruning and training fruit trees,

Fruit thinning: Bearing fruit trees have the potential of setting more fruit than they are capable of carrying. If all the fruit were left on the tree, they would be small at maturity.
More important, the tree would have very few, if any, blossoms the following year. Fruiting is a devitalizing process, and with the competition of a heavy crop, there would be very little manufactured food reserves and nutrients available for flower bud formation. The net result is biennial bearing. To overcome this tendency to bear fruit in alternate years, fruit thinning should be practised.

Pollination: All the precautions to ensure the production of flower buds may be taken, but without proper pollination, trees will still fail to bear. Many fruit species or cultivars within a species either cannot produce fruit or will produce very little when pollinated with their own pollen. Such trees require pollen from another cultivar of the same species to be fruitful. This is true for apples, pears, hybrid plums, and sweet cherries. Most peaches, sour cherries, and apricots are capable of setting good crops without cross-pollination.

Pest management: Insect and disease control often are thought of as means of producing quality fruit. However, insects or diseases that attack the foliage of a fruit tree can affect its potential to produce flower buds. If the attack is severe enough, the trees may fail to bear. Timely applications of recommended pesticides will control most pest problems on fruit trees.

\section{Factors responsible for biennial bearing}

Several factors like, age and size of shoots, climatologically factors, carbon/ nitrogen ratio and hormonal balance have been responsible for biennial bearing in mango fruit plants. These factors are described below as; Age and size of shoots Growth in mango takes place in different flushes, which vary in different parts of the country. Early initiation and cessation of growth, followed by a definite dormant period, will helps the shoots 
to attain proper physiological maturity which is essential for fruit-bud initiation. In the case of regular bearing cultivar Rumani, December emerged shoots are capable of producing the flower buds in the following February. However, the growth of mango shoots is purely a varietal feature and fruit-bud differentiation in regular bearing varieties is an annual feature. In biennial bearing varieties, it is governed by 'on' and 'off' year phase of the trees rather than by the time of origin and cessation of growth of shoots. In an 'on' year, shoots of any size or maturity differentiate flower buds whereas in an 'off' year, even the shoots of requisite size and maturity fail to flower. Carbon / nitrogen ratio That irregular bearing in mango was caused by nutritional deficiency, especially by nitrogen.

In fruit plants, nitrogen and carbohydrate reserves play important role in flower bud initiation, even if these do not form the primary cause of the phenomenon of biennial bearing. It is quite probable that an accumulation of these compounds may create favourable conditions for the synthesis and action of the substances responsible for flowering. The accumulation of these compounds may create a favourable condition for the synthesis and action of the substances actually responsible for flower induction in these plants. There was an increased accumulation and metabolism of carbohydrates, proteins and amino acids constituents in the mature plants compared with the juvenile plants (Davenport, 1997). The translocation of phosphorus is involved in controlling the alternate bearing in mango. Hormonal balance Biennial bearing problem in mango appears to be closely associated with the fruit development process and the inhibitory influence of the developing fruits on vegetative growth. Higher levels of auxin like substances and an inhibitor (similar to ABA) and lower levels of Gibberellin (GA3) like substances are vital for a floriferous shoots in mango. The inverse relationship between the level of endogenous inhibitor in the shoot and vegetative growth.

They are also suggested that higher inhibitor content promotes flowering in mango. Agrawal et al., (1980)(1) described cytokinine-like substances isolated from stem tips of an alternate-bearing cultivar in 'on' and 'off' years. The estimated levels of gibberellins in apical buds for 6 months prior to the flowering season were reported to be higher in the 'off' year than in the 'on' year of an alternate-bearing cultivar (Pal and Ram, 1978)(29). Climatological factors Adverse climatic conditions like rainfall, high humidity and low temperature sometimes convert an 'on' year into 'off' year directly or by promoting the incidence of diseases like powdery mildew and anthracnose. Frequent frost or low temperatures during the flowering period adversely affect the fruit set, thereby turning an 'on' year into a year of low or no production crop. Chen et al., $(1985,87)(8,9)$ reported that the temperature is considered to be key environmental factor, with low temperatures $\left(19^{\circ} \mathrm{C}\right.$ in day and $13^{\circ} \mathrm{C}$ in night) favourable for fruit bud differentiation. Cultural practices The earlier reports that biennial bearing problem is far most part a nutritional one appears to be wrong because liberal manuring and irrigation given to the 20yearsold biennial bearing trees failed to induce regular cropping.

Thus, it is evident that while nutritional requirements of the fruit trees must be met for optimum performance of the trees, biennial bearing cannot be overcome by the addition of nutrients. Crop load Generally, moderate blossoming is one of the chief conditions of annual fruit bearing in fruit trees. The number of fruits retained till harvest is a varietal feature. The total number of fruits that are harvested is important because of their 
deleterious influence on the production of new shoots and their subsequent fruit-bud differentiation. Therefore, the fruit load appears to be the main conditioning factor for 'on' or 'off' year in mango. The potential of shoot to form flower buds will depend on the floriferous condition of the tree, which in turn will be determined by the amount of fruit load carried by the tree in the previous year (Singh, 1971)(34). Control measures for biennial bearing in mango Different control measures are used for the implying the regular bearing in mango. These control measures are described below as; Proper upkeep and maintenance of orchards. Deblossoming is a more severe form of fruit thinning, employed to conserve the reserves of the shoots which could otherwise be depleted later on in the development of fruits. Deblossoming of the panicles with NAA @ 200ppm during 'on' year effective for the controlling biennial bearing in mango. Majumder et al., 1976(25) reported that the alternate bearing in mango reduced by the removal axillary panicles. The partial or complete removal of flowers in the 'on' year increases flowering the next year. Chemical regulation Ethephon has also been successful use in India for increasing flower intensity of mango cultivars Langra and Dashehari during off years (Chadha and Pal, 1986)(6). Chen, 1987(18) described precocious bud break and flowering of mango shoots in response to an early October application of 100 ppm 6- Benzyl amino purine (6-BA). The paclobutrazol induced enhancement in $\mathrm{C}: \mathrm{N}$ ratio has been reported in mango consistently higher production of total sugars and reducing sugars with peak availability at bud burst in apical buds (Upreti et al., 2014)(37).

Besides reducing the gibberellin biosynthesis, PBZ enhances the ABA content. PBZ induced increase in $\mathrm{ABA}$ content could be due to the modification in the isoprenoid pathway which is common for $\mathrm{ABA}$ and gibberellin biosynthesis (Upreti et al., 2013)(36). Potassium nitrate is currently recommended in the Philippines for inducing uniform flowering and for the production of off-season fruits in the 'Pico' and 'Carabao' cultivars (Madamba, 1978)(24).Davenport (2003)(10) reported that bud break was initiated three months later by a foliar application of KNO3 in weakly inductive condition (during warm temperature condition) maximum response was observed at about four weeks. Plant growth retardants have been evaluated to stimulate early or more intense flowering, especially in the 'off' year of alternatebearing cultivars (Davenport and NúñezElisea, 1997)(11).The efficacy( of daminozide and cycocel for increasing flowering in the 'off' season of alternate-bearing cultivars has been studied (Rath and Das, 1979; Rath et al., 1982)(30,31), together with their ability to stimulate early flowering (Suryanarayana and Rao, 1977; Chen, 1985)(35,8). Smudging Smudging is an early commercial method for inducing flowering in mango (Wester, 1920).Sen and Mallik, 1947(33) reported that smudging has a stimulating effect on growth, but the nature of growth, vegetative or reproductive, depends on other factors and concluded that smudging can induce flowering only if the shoot is in condition to flower in mango cultivar Langra. Pruning In mango trees, pruning is necessary to control the canopy size and to produce high quality marketable fruits by facilitating better ventilation, high penetration of sunlight, easy application of plant protection chemicals and ease in harvesting (Burondkar et al., 1997; Gross, 1996)(5,16).

Pruning play an important role in mango trees like encouraging the branching of young trees particularly in cultivars which do not branch readily on their own, stimulating the development of new shoots and maintaining the tree size (Oosthuyse, 1994)(28).Tip pruning forces a synchronized flush from 
pruned stems, which results in synchronized flowering in Keitt mango (Davenport et al., 2006)(12). The age of the last flush is the dominant factor regulating flowering of mango. Stems must be generally about 4 to 5 months to be able to induce for flowering in the next year (Davenport, 2003)(3).Pruning is effective for early and higher accumulation of reserves by enhancing uniform post-harvest flushing and reduces flowering variation (Oosthuyse, 1994)(28). Growing regular bearing cultivars Totapuri, Rumani, Neelum and almost all hybrids of mango are having regular bearing nature. However, two cultivars, Neelum and Totapuri, which are regular bearers, have been extensively used as the parents in a hybridization programme to transfer the regular bearing habit to hybrids. Neelum has been observed to be a good combiner and has contributed to the evolution of many regular bearing Indian hybrid cultivars. The regular bearing Florida cultivars i.e. 'Tommy Atkins', 'Keitt', etc. are also have potential as parents. It is apparent that floral initiation in trees is controlled by a range of factors which may include environmental factors, developmental issues and other interactions with vegetative growth and PGRs. for flowering in shoots high level of starch, some auxin like regulators and inhibitors and a low level of gibberellins may be seemed favourable. Maintain of regular bearing in mango is necessary not only for yield sustainability but also for yield increase. Use of some plant growth regulator (paclobutrazol), shoot pruning, use of fruit set chemicals etc. are found to be the most promising approaches for ensuring flowering and enhancing fruit yield under commercial cultivation

Table.1 Average age of fruit trees

\begin{tabular}{|l|l|}
\hline \multicolumn{2}{|c|}{ Average bearing Age } \\
\hline Crops & Times in Year \\
\hline Apple & $4-6$ \\
\hline Apricot & $3-5$ \\
\hline Cherry, sour & $3-5$ \\
\hline Cherry, sweet & $5-8$ \\
\hline Peach & $3-4$ \\
\hline Pear & $4-6$ \\
\hline Plum & $3-5$ \\
\hline
\end{tabular}

Fig.1 High density Orcharding bearing in Mango

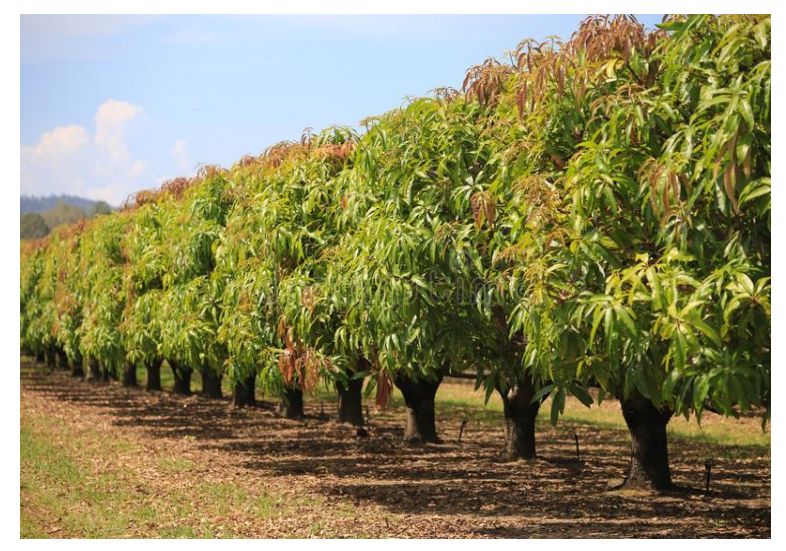


Fig.2 Flowering and fruiting in off and on Year

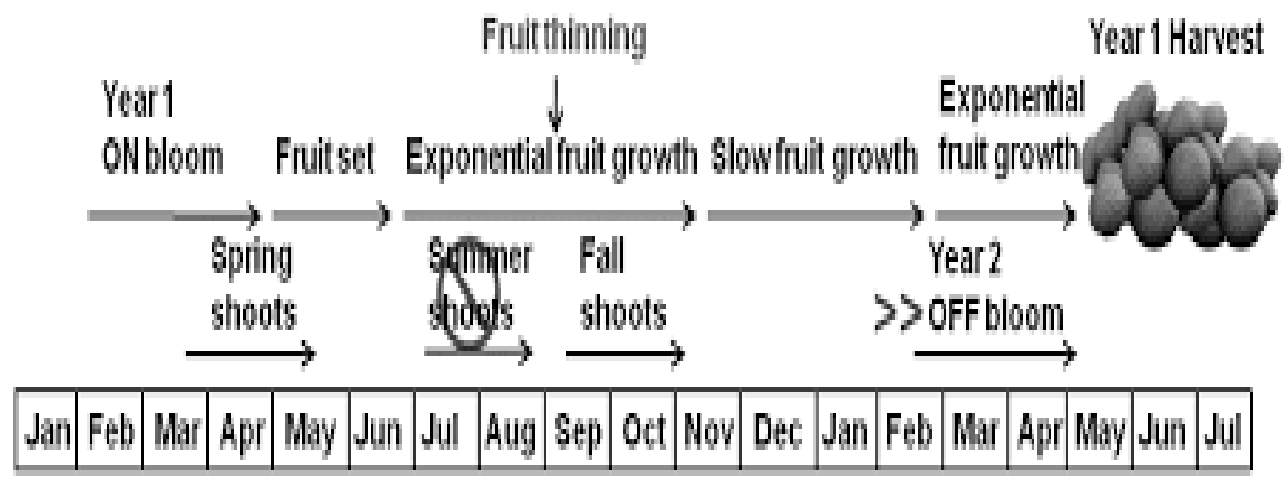

Fig.3 Training and Pruning in Avocado

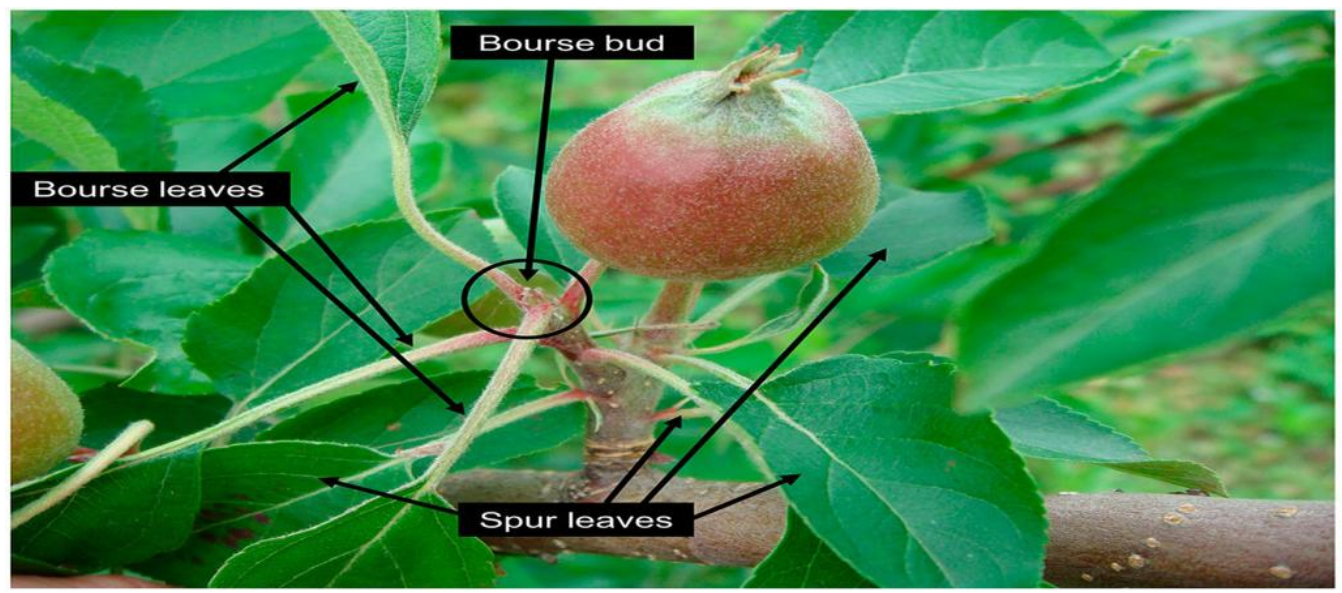

Fig.4 Alternate Bearing (On and off Year) in Mango (Mangifera indica L.)

Plant height, flowering, yield and quality including alternate bearing can be overcome by various horticultural practices like pruning, thinning of fruits, use of chemicals like Paclobutrazol etc. out of these use of Paclobutrazol is commonly practiced by the horticultural growers.

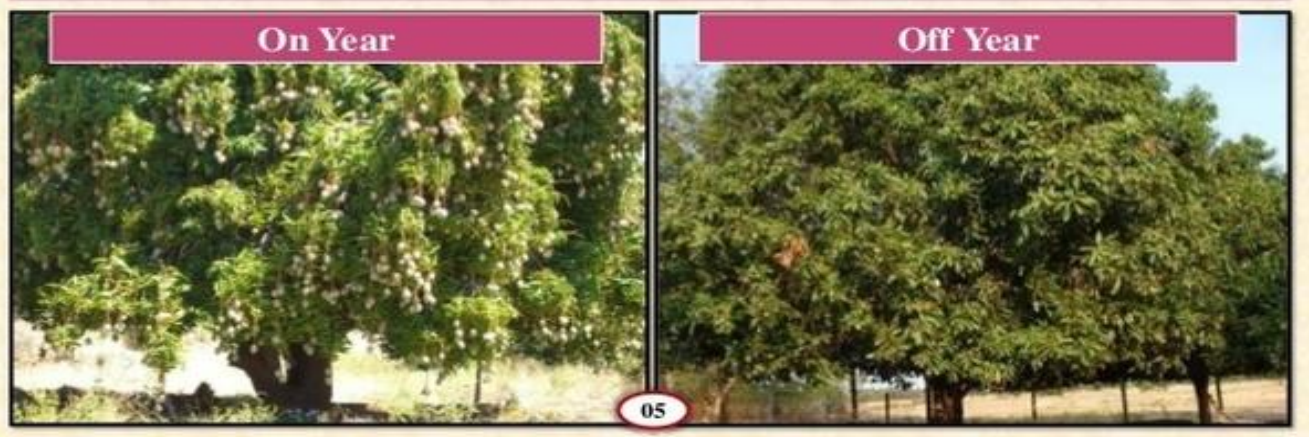




\section{Causes for alternate bearing}

The exhaustion of tree during the period of heavy crop load and vigorous vegetative growth with high gibberellin hormone content at the time of flower bud differentiation and imbalance in Carbon / Nitrogen ratio has been considered as some of the major causes for biennial bearing or alternate bearing in mango

Management: Planting of fairly regular bearing varieties like Amrapali, Banganpalli, Bangalora and Neelum are suggested for getting regular fruits, but most of the commercially grown varieties in North India, like Dashehari, Safeda, Chousa and Langra are alternate bearers. In such trees, regularity can be achieved by performing a series of management practices such as pruning, flower induction, fertilizer application, irrigation and pest control. Mango normally flowers during February-March and is ready for harvest during June-July. Fruits are borne largely on previous year's shoots, so pruning should not be very severe. Light pruning restricts the vegetative growth up to some extent and activates the quiescent fruit bearing buds by redistributing the endogenous hormonal substances and favours flowering, fruiting and improves fruit yield. After harvesting the fruits, troop off branches to open the centre. Also remove dead wood, weaker branches and criss-cross branches to allow sunlight to enter the canopy.

Site and cultivar selection: Based on the bearing tendency, apple varieties have been classified into three groups (Jonkers, 1979)(75).

Regular bearers: Early Worcester, Golden delicious, Golster, Jonagold, Rome Beauty Moderate bearers: Delicious group, Golden spur, Granny Smith, Jonagold, McIntosh, Northern Spy, Red Gold and Rhode Island Green
Distinctly alternate bearers: Baldwin, Benoni, Boskoop, Cox Orange Pippin Selection of regular bearing varieties and planning of orchards in a site with optimal climatic conditions with good soil and physical properties reduces the risk of alternate bearing and other cropping irregularities. Spring flowering deciduous orchards are preferably planted on sites with low risk of frost or freeze damage

Cultural practices and pollination: Since the phenomenon of alternate bearing is natural and is internally regulated by the plant, good crop management practices are essential to minimize its occurrence. In general, flower formation is promoted in perennial fruit trees under optimal growing conditions. Optimal plant growth can be maintained by practising annual pruning, regular irrigation and maintenance of optimal nutrient levels in soil and plant tissue along with judicious use of pesticides. Honey bees are effective pollinators for apple. Setting the beehives in apple orchards during the blooming period enhances the pollination and fruit set. Management of orchard with above cultural practices does not reduce the risk of alternate bearing directly but the risk of cropping irregularities will be managed up to some extent

Crop load management: This is the most important management practice for minimizing alternate bearing. Crop load adjustment is very important for regulation of yields in the current season as well as for next season. Crop load management is done by thinning and pruning methods

Chemical thinning: Some of the chemical thinners such as Lime sulphur, carbamates (Carbaryl, Oxymyl @ 600ppm), NAA (2.520ppm), 6-BA (75-175ppm), Ethephon (150$600 \mathrm{ppm}$ ) are used for the chemical thinning process in apples. 
Pruning: Pruning removes bearing surface (fruit buds) and stimulates vegetative growth from remaining buds. This promotion of vegetative growth inhibits many of the remaining buds from becoming floral.

Hand thinning: Hand thinning serves like a chemical thinning process. In this method, excessive crop load is removed by hand thinning. Hand thinning is labour-intensive, and it must be practised early in the growing season in order to have a beneficial effect on the alternate bearing.

Return Bloom Sprays: Chemical thinning alone may not be adequate to promote annual bearing in many of the commercially important apple cultivars that possess a strong genetic tendency towards alternate bearing phenomena. In such cases, plant growth regulators that directly stimulate flower formation should be used. NAA @ 3-5 ppm or Ethephon@100-200 ppm may be used, starting from five weeks after bloom to eight weeks after bloom to get quality yields.

Pruning: Pruning the branches is a preemptive measure to reduce excess fruiting in one year to prevent reduced crops in the following year. When some of the flower buds are removed by pruning, it promotes vegetative growth, reducing the chances of heavy fruit setting.

Thinning: Thinning out the fruits within the first few weeks after the flower petals fall is found to be effective against biennial bearing. When the energy requirement for fruit bearing is reduced, it promotes the flower formation process of the coming year. Thinning may be performed by hand for the home gardener, or through the use of chemicals for commercial growers.

Hand thinning: For a tree fruiting every other year, a heavy crop can be reduced by manually thinning the fruits when they're one-third their normal size. With apples, all except the biggest fruit in a bunch can be removed by hand picking. Only one fruit should be allowed to grow in every 10 inch (25 cm.) span on the branch. For apricots, peaches and pears, a gap of 6 to 8 inches (15 to $20 \mathrm{~cm}$.) is ideal.

Chemical thinning: Certain chemical agents are used to control biennial bearing in trees grown commercially. These chemicals effectively thin out heavy crops and encourages even crops. In commercially grown orchards, this labor-saving technique is preferred to manual thinning. Vydate $\AA$, Amid Thin $®$, and Fruitone $®$ are some of the products used for this purpose. In addition to reducing heavy crops, active measures to promote flowering and fruit setting may be necessary to prevent alternate bearing. They include: Use of growth regulators to induce flowering Use of phosphorus fertilizers, such as bone meal Planting pollinizer varieties to help with cross pollination Introducing beehives at the time of flowering to ensure pollination Young trees must be carefully pruned and protected from water stress and chemical imbalances to discourage the tendency for biennial bearing. There are also many cultivars resistant to alternate bearing.

Effect of Palobutrazol: Biennial fruits bearing or Irregular bearing or Alternate bearing is serious problems in fruit cropsleading to considerable decline in their fruits production potentials. Alternate bearing means "a condition at which high or optimum fruit production in on year or higher and certain year bear little or no fruit (off-year). Flower initiation is very important because it is the first step towards attaining fruit. Recent trials have clearly shown that while the extent (quantity) of flowering affects yields, time of flower emergence has a significant influence on time of fruit maturity. Early flowering 
clearly resulted in early fruit maturity, therefore, one method to manipulate flowering isto use the plant growth regulators particularly the growth retardants like paclobutrazol. Paclobutrazol isa member of the triazole plant growth inhibitor group that is responsible restricts vegetative growth and induce flowering in biennial bearing several fruit crops.

Paclobutrazol (PBZ) is responsible for the induction and manipulation of flowering, fruiting and tree vigor in biennial bearing fruit crops. The application of paclobutrazol in the soil promotes flowering and increasing yield in many fruit crops. Besides reducing gibberellins level, paclobutrazol increase. cytokinin contents, root activity, and $\mathrm{C}$ : $\mathrm{N}$ ratio, whereas its influence on nutrient uptake lacks consistency. It also affects microbial population and dehydrogenase activity in soil. Paclobutrazol has been characterized as an environmentally stable compound in soil and water environments with a half-life ofmore than a year under both aerobic and anaerobic conditions. However, when it is applied in optimized rate the residual concentration detected will not be above quantifiable level $(0.01 \mathrm{ppm})$ in soils and fruits. It is extensively studied due to its high potential for controlling plant growth and development. PBZ which is also known as different commercial names such as pp333, cultar, bonzi; sadabahar, parley, clipper, etc, is an important growth retardant.

Paclobutrazol has been effective in controlling the growth of a wide range of fruit crops by inhibiting both sterol and gibberellin biosynthesis. The main effect of paclobutrazol in the plant is the inhibition of gibberellin biosynthesis, which reduces change in the sink source relationship by reallocating the carbohydrate source towards other organs of the plant than the shoot apex.
Paclobutrazol is effective not only in flower induction but also in early and off-season flower induction in fruit crops. The Mode of action of plant growth retardants such as paclobutrazol is highly specific to cultivar, rate of application, cultivar, developmental stages, and climatic condition. Paclobutrazol holds considerable promise in the manipulation of flowering, yield, and vigor in fruit crops. However, its high potency for harmful to nature, slow mobility in the orchard soil, persistence in soil and fruit over its long term use. Plant growth retardants are being used widely in chemical manipulation of growth and development by modifying associated biochemical and physiological processes. Among them, paclobutrazol is considered as one of the most versatile plant growth retardant which restricts vegetative growth and induces flowering in many fruit crops like apple, pear, peach, citrus, mango, avocado, litchi, temperate fruits, and nuts. Paclobutrazol (PBZ) is a triazole derivative with which plays an important role in regulating excessive vegetative growth, enhancing and advancing flowering, inducing early bearing, managing biennial bearing tendency, establishing a high-density plantation. Why the application of paclobutrazol in fruit crops? The biennial bearing is a very serious problem in fruit crop production. Because biennial bearing or alternate bearing in fruit crops is a major problem faced by fruit growers. This problem causes great economic loss to the growers. Irregular and alternate bearing problem-solve through paclobutrazol is commonly practiced by growers. Paclobutrazol is a synthetic plant growth retardant, which has been used in fruit tree crops to control vegetative growth and to induce flowering.

The alternate flowering in fruit crops might be due to improper orchard management practices, environmental factors, varietal character, Imbalance of hormone, etc. Mode 
of action of paclobutrazol Gas chromatography-mass spectrometry confirmed that PBZ was taken up by roots and translocate acropetally via the xylem to stems and accumulated in leaves. Paclobutrazol is having anti-gibberellins activity which blocks the conversion of entkaurene to ent kaurenoic acid in the gibberellins biosynthetic pathway, which is responsible for cell elongation and cell division and ultimately retards plant growth. When gibberellin production is inhibited, cell division still occurs, but the new cells do not elongate. That results in the production of shoots with the same numbers of leaves and internodes compressed into a shorter length. Paclobutrazol treated trees show increased production of the hormone abscisic acid and the chlorophyll component phytol, which are beneficial to tree growth and health. It also induces morphological modifications of leaves, such as smaller stomatal pores, increased number, and size of surface appendages, thicker leaves, and increased root density that may provide improved environmental stress tolerance and disease resistance and it also has some fungicidal activity due to its capacity as a triazole to inhibit sterol biosynthesis.The amount of paclobutrazol residue left in the soil or plant parts would appear to depend on themethods of application, doses and the crop.Guideline for use of paclobutrazol on fruit crops Paclobutrazol should be applied to healthy trees. Tree base should be kept weed-free before and after its application. Adequate moisture in the soil at the time of application and for the following 40-50 days is essential. Paclobutrazol treated trees start producing inflorescence in 3-4 months of application.

This flush of inflorescence as well as new vegetative flushes and flowers should be regularly protected from the attack of insects, pests, and diseases. Paclobutrazol treated trees are expected to bear a good crop every year.
Therefore, twice there commended dose of fertilizers and organic manures should be fed to the tree from the second year of paclobutrazol application. Time of application of paclobutrazol in fruit crops. Usually, it is applied as a soil application in the month of September-November in the case of mango. The growth retardant paclobutrazol is applied after harvest as a soil application or foliar application. Paclobutrazol is applied as Cultar @ $23 \mathrm{SC}$ to the tree basin soil by making a 15 $\mathrm{cm}$ deep and $30 \mathrm{~cm}$ wide-furrow at a radial diameter of $1 \mathrm{~m}$ from the tree trunk during last week of September inmango and Litchi. Method of application of paclobutrazol Paclobutrazol applied asFoliar application Soil application TSLP method Soil and plant trunk injection incorporating in nutrient solution Paclobutrazol must be applied directly to the soil due to its low solubility, long residual activity, and lack of efficient foliar uptake. Soil application rather than the foliar application of paclobutrazol hasbeen found to be more responsive in suppressing the vegetative growth and enhancing there productive growth in mango trees. Paclobutrazol is a potent inhibitor of gibberellin biosynthesis and can be applied as an overall spray,as a soil drench or by way of trunk painting; better results have been achieved when used as a soildrench, either in the root zone or the collar region of the tree. The required quantity is mixed in approximately $1 \mathrm{~L}$ of water and poured onto the soil around the trunk in a circular band.

The proper care of fruit orchards provides for the necessary concentration of nutrient substances in the plant cells, especially protein matter, and for an optimal ratio of carbohydrates and nitrogen, which stimulates the setting of flower buds in the harvest year for fruiting in the next year. In this way, annual harvests are ensured. To obtain a good harvest of high-quality fruit every year a tree must have 30 to 60 leaves for each fruit. This 
is possible if the tree has many annual shoots; thus, shoot formation is an important factor in high yield. Moderate flowering is one of the most important conditions for annual fruiting. Only a moderately flowering tree is capable of producing a large harvest and setting flower buds for the following year's harvest. Abundantly flowering pome trees (apple and pear) should have their excess flowers or set fruits removed at an early stage of development by growth substances to preserve nutrient matter for the formation of the remaining fruits. Alternate bearing characterizes only some plant varieties. For example, some varieties of apple (Slavianka, Pepin shafrannyi) yield annually, others (Antonovka obyknovennaia, Anis polosatyi) require special maintenance in order to do so, and still others (Kandil'-Sinap, Grushovka moskovskaia) are marked strictly by alternate bearing. Various agricultural procedures and the stocks to which varieties are grafted also influence the periodicity of fruiting.

\section{Vegetative growth response to soil-applied PBZ}

In the absence or presence of GA Growth form Total number of shoots per tree in Trial A was not affected the year after PBZ application but was reduced the year after. The reason for this could be that the decision for shoot number (growing points) would have been made between November/ December 1992 and PBZ was applied in September 1993. At that stage PBZ was not expected to affect the shoot number. GA application at that stage in November/December caused an increase in shoot number in 1994 and a reduction in 1995. The total shoot length and total bud number were significantly reduced with $\mathrm{PBZ}$ alone the year after PBZ application with a prominent reduction in the second year after PBZ application. This shows that GA is not producing further vegetative growth through increasing shoot number (growing points) but still increasing the total shoot length and total bud number across 2 years. However in the presence of PBZ, GA significantly and successfully reversed the effects of PBZ or GA on vegetative growth characteristics and provided a balanced vegetative growth well below that of the control for 2 years. Reproductive growth response to soil-applied PBZ in the absence or presence of GA Fruit yield. In this study PBZ use alone decreased the fruit yield the year after PBZ application with a slight reduction in yield in the next year as well. However, the stability of fruit yield was increased across the 2 years. Bienniality indices based on fruit number show the extent of year-to-year variation in yield, the larger the index value, the greater the tendency for year-to-year variation. Based on these indices PBZ alone slightly increased the $\mathrm{BI}$ values from 0.21 to 0.23 .

The bienniality of the fruit yield was thus increased by PBZ use alone in agreement with our earlier study (Khurshid et al., 1996a) and some other reports on high-density dwarf trees by Steffens et al., (1993) and Zimmerman \& Steffens (1995). The reason for lower yield with PBZ in these trees would be the smaller tree size resulting from PBZ use combined with the use of single tree plots which would have lead to crowding of the treated trees. The other trials where PBZ increased yield used large buffered plots (Khurshid et al., 1996a,b), which would have eliminated yield reduction because of competition. PBZ plus GA combination treatments caused recovery of yield for the next 2 years in Trial A and this brought down the BI values from 0.23 to 0.20 . This was despite vegetative growth still being reduced and therefore the trees still having substantial competitive pressure. In Trial $\mathrm{B}$, where trees received PBZ before the GA treatment, the fruit yield completely recovered the year after treatment and BI values were reduced 
significantly from 0.27 to 0.18 . These results suggest application of GA to the trees which had already received PBZ 2 months previously reduced fruit bienniality more efficiently than GA application before PBZ treatment to the trees. Total fruit number per tree Total fruit number per tree followed a similar trend to fruit yield and was reduced with PBZ application. However, in the presence of GA and PBZ fruit number recovered substantially. The reverse PBZ effect by application of GA has been previously reported (Greene 1991; Steffens et al., 1992). GA can therefore be used-as a tool to increase fruit yield and reduce bienniality and in conjunction PBZ to control vegetative growth, when applied in the correct manner.

In conclusion alternate bearing has been one of the major problems. Most of the south Indian varieties are regular-bearer, whereas north Indian ones alternate-bearer. Paclobutrazol is a promising chemical for flower induction in mango. Soil drenching with paclobutrazol $(5 \mathrm{~g}-10 \mathrm{~g} /$ tree $)$ results in minimum outbreak of vegetative flushes during September to October giving an early and profuse flowering and more annual yield without affecting fruit size and quality.

\section{References}

1. Agrawal, A., Ram, S. and Garg, G.K. ,1980. Endogenous cytokinins of mango (MangiferaindicaL.) shoot tips and their significance in flowering. Indian Journal of Experimenta lBiology, 18: 504-509.

2. Bangerth F., 2009. Floral induction in mature, perennial angiosperm fruit trees: similarities and discrepancies with annual/biennial plants and the involvement of plant hormones, Scientia Horticulturae, , vol. 122 (pg. 153-163)

3. Bangerth F. 2006. Flower induction in perennial fruit trees: still an enigma?, Acta Horticulturae, , vol. 727 (pg. 177195)

4. Buban T, Faust M. 1982. Flower bud induction in apple trees: internal control and differentiation, Horticultural Reviews, vol. 4 (pg. 174-263)

5. Burondkar, M.M., Gunjate, R.T., Magdum, M.B., Govekar, M.A. and Waghmare, G.M.(1997). Increasing productivity of mango orchards by pruning and application of paclobutrazol.Acta Hort., 455: 367-74.

6. Chadha, K.L. and Pal, R.N. (1986). MangiferaindicaL. In: Halevy, A.C. (ed.) CRC Handbook of Flowering, Vol. 5: 211- 30.

7. Chan B, Cain J. 1967. The effect of seed formation on subsequent flowering in apple, Journal of the American Society for Horticultural Science, , vol. 91 (pg. 63-67)

8. Chen, W.S. (1985). Flower induction in mango (MangiferaindicaL.) with plant growthsubstances. Proceedings National Science Council Part B, Life Sciences (Republicof China),9: 9-12.

9. Chen, W.S. (1987). Endogenous growth substances in relation to shoot growth and flower bud development of mango.J. Amer. Soc. Hort. Sci., 112: 360-363.

10. Davenport, T.L.(2003). Management of flowering in tropical and subtropical fruit tree species.Hort. Sci., 38: 1331-1335.

11. Davenport, T.L., Nunez-elisea, R.(1997). Reproductive physiology. In: Litz RE (ed), The Mango, Botany, Production and Uses.CAB International, Wallingford Oxon. pp. 69-146.

12. Davenport, T.L., Ying Z., Kulkarni V. and White T.L.(2006). Evidence for a translocatableflorigenic promoter in mango.Sci. Hort., 110: 150-159. 
13. Foster T, Johnston R, Seleznyova A. 2003. A morphological and quantitative characterization of early floral development in apple (Malus $\times$ domestica Borkh.), Annals of Botany, vol. 92 (pg. 199-206)

14. Goldschmidt EE, Golomb A (1982) The Carbohydrate Balance of Alternatebearing Citrus Trees and the Significance of Reserves for Flowering and Fruiting. J Am Soc Hort Sci 107: 206-208..

15. Grochowska M, Karaszewska A. 1976. The production of growth promoting hormones and their active diffusion from immature, developing seeds of four apple cultivars, Fruit Science Reproduction, vol. 3 (pg. 5-16)

16. Gross, G.R.(1996). Pruning of mango to increase yield. Acta Hort., 455: 538542.

17. Hanke MV, Flachowsky H, Peil A, Hattasch C., 2007. No flower no fruit genetic potentials to trigger flowering in fruit trees. Genes Genomes Genomics 1: $1-20$.

18. Harley C. 1942. Investigations on the cause and control of biennial bearing of apple trees, USDA Technical Bulletin, , vol. 792 (pg. 1-58)

19. Hoad GV., 1978. The role of seedderived hormones in the control of flowering in apple, Acta Horticulturae, , vol. 80 (pg. 93-103)

20. Jonkers H. 1979. Biennial bearing in apple and pear: a literature survey, Scientia Horticulturae, vol. 11 (pg. 303307)

21. Link H. 2000. Significance of flower and fruit thinning on fruit quality, Plant Growth Regulation, , vol. 31 (pg. 17-26)

22. Luckwill LC. 1974. A new look at the process of fruit bud formation in apple, Proceedings of the XIXth International Horticultural Congress, vol. 3 (pg. 237246)
23. Luckwill LC. Luckwill LC, Cutting CV. 1970. The control of growth and fruitfulness of apple trees, Physiology of tree crops, LondonAcademic Press(pg. 237-254)

24. Madamba, J.C. 1978. The Philippines recommends for mango. Philippine Council for Agriculture and Resources Research. Maiti, S.C., Basu, R.N. and Sen, P.K. (1972). Chemical control of growth and floweringin MangiferaindicaL.

ActaHorticulturae,24: 192-195.

25. Majumder, P.K., Sharma, D.K., Singh, M.P. and Singh, R.N. 1976. Improve productivityof malformed mango trees. Journal of Indian Horticulture, 20: 7-8.

26. Monselise S, Goldschmidt E. 1982. Alternate bearing in fruit trees, Horticultural Review, vol. 4 (pg. 128173)

27. Neilsen JC, Dennis FG. 2000. Effects of seed number, fruit removal, bourse shoot length and crop density on flowering in 'Spencer Seedless' apple, Acta Horticulturae, vol. 527 (pg. 137146)

28. Oosthuyse, S.A., 1994. Pruning of sensation mango trees to maintain their size and effect uniform and later flowering. South African mango grower's Assoc., Year book. 14:1-5.

29. Pal, S. and Ram, S., 1978. Endogenous gibberellins of mango shoot-tips and their significance in flowering. Scientia Horticulturae,9: 369-379.

30. Rath, S. and Das, G.C., 1979. Effect of ringing and growth retardants on growth and flowering of mango. Scientia Horticulturae, 10: 101-104.

31. Rath, S., Das, G.C. and Singh, R.L. 1982. Manipulation of flowering in mango by forcingthe dormant buds. Bangladesh Horticulture,10: 39-41.

32. Samach A, Onouchi H, Gold SE, Ditta 
GS, Schwarz-Sommer Z, Yanofsky MF, Coupland G. 2000. Distinct roles of CONSTANS target genes in reproductive development of, Arabidopsis. Science, , vol. 288 (pg. 1613-1616)

33. Sen, P.C. and Mallik, P.C. 1947. Effect of smudging on Mango. Indian J. Hort., 5 (2): 29-34

34. Singh L. 1948. Studies on biennial bearing. III. Growth studies on 'on' and 'off' year trees, Journal of Horticultural Science, , vol. 24 (pg. 123-148)

35. Suryanarayana, V. and Rao, V.N.M. (1977). Ascorbic acid changes in shoots of mango cv.Mulgoa as affected by growth retardants in relation to flowering. Indian Journal of Plant
Physiology,20: 88-90.

36. Upreti, K.K., Reddy, Y.T.N., Shivuprasad, S.R., Bindu, G.V., Jayaram, H.L. and Rajan, S., 2013. Hormonal changes in response to paclobutrazol induced early flowering in mango cv. Totapuri. Sci. Hort., 150: 414-418.

37. Upreti, K.K., Shivuprasad, S.R., Reddy, Y.T.N. and Rajeswara, A.N., 2014. Paclobutrazol induced changes in carbohydrates and some associated enzymes during floral initiation in mango (Mangiferaindica L.) cv. Totapuri. Indian J. Pl. Physiol., 19: 317- 323.

\section{How to cite this article:}

Ashok Kumar, B. D. Bhuj and Singh, C. P. 2021. Alternate Bearing in Fruits Trees: A Review. Int.J.Curr.Microbiol.App.Sci. 10(01): 1218-1235. doi: https://doi.org/10.20546/ijcmas.2021.1001.146 